\title{
IMPROVING STUDENTS' WRITING SKILL THROUGH CUE CARD METHOD
}

\author{
Ika Sastrawati \\ English Education Department, Faculty of Teacher Training and Education \\ Muhammadiyah University of Makassar \\ ikasastrawati@unismuh.ac.id
}

\begin{abstract}
This research aimed to find the use of Cue Card Method improve the students writing skill at Eight Grade Students of SMP Bajiminasa Makassar. The method of this research was classroom action research consisted of two cycles. One cycle consisted of four meeting. it meant that were eight meetings for two cycles. This classroom action research was done at SMP Bajiminasa Makassar for English subject. As subject in this research was class VIII.A Junior High School in 2012-2013 academic year with student' number as about 36 students'. Those consisted of 26 women and 10 men. instrument was writing test and observation. The research findings indicated that the application of cue card method was effective and significant in improving the students' writing skill especially it's focus on students content and vocabulary. It was proved that the mean score of DTest was 5.64, Cycle I 6.13 and after conducted Cycle II improved to 8.23 and based two cycle researcher found percentage improvement that is from D-Test to Cycle I is $13.24 \%$ and from Cycle I to II is 29.70 and D-T to Cycle II $46.35 \%$.

Based on the result of the research, it can be concluded that the use of cue card method improves students' writing skill and class condition. Therefore, it is recommended that the teachers use cue card media in teaching writing.
\end{abstract}

Keywords: Writing Skill, Cue Card Method

\section{INTRODUCTION}

Writing is an essential part of learning. Academically, writing is main point for developing ideas and feeling by considering some important components and writing processes. Writing can also be as an independent learning tool that can be done by students to write their own idea or main idea and fulfill their writing assignment and to enrich their skill to write of everything. As addition, writing was not only to develop idea but also to develop feeling in mind.

Writing is admitted widely as one of the most difficult skills that students ever do, either in foreign language or in their native language. Raimess (1983) says that many adult native speakers of a language find writing a difficult skill. Similiarly, Schwegler (1985) says that writing is one of the hardest things that 
people do and writing was hard because it requires thinking. Klein (1985) says that writing is the ability to put pen and paper to express ideas through symbols.

There are many methods and techniques in teaching and learning writing. If the method of teaching English is suitable for the students, they would enjoy it. So, the students would enhance their ability in the language. Besides that, the teacher gathers some information about the students' progress and then doing the evaluation to measure the students' achievement. It is better to give the students some assessments to measure their achievement in writing.

Aware, there are many weaknesses of written assessment, developing system assessment which integrates and give more attention to develop whole of students is written put on documentation in one small project called cue cards.

In final project, cue card is introduced as one of the teaching media. Cue card is card with words or picture on, which are used to encourage the students to respond (Harmer, 2001:134). Cue card is interesting due to its simplicity and attractiveness. Besides inexpensive, the process of making it was not quite complicated. A teacher, sometimes, needs creativity to make the cards more attractive. Cue card as the modification of picture has many advantages, one of which is that it is clearly visible. Thus, when students are asked to describe something/someone in detail, cue cards method can help them to produce the description easily.

\section{CONCEPT OF WRITING}

The meaning of writing according to the Oxford Learner's Pocket Dictionary (2005) produces something in written form so that people can read. According to Oshima and Hogue (1997) states' writing is developing of the activity. It means that when we want to write down for the first time, we should know about what will we want to write. According to Troyka (1987) states' writing is a way of communicating a message to a reader for a purpose

The process of the written is how to create the creative idea and write down it into essay form Gebhard (1996). As the Hadisubroto (2005) by the book Belajar Sendiri Mengarang Bahasa Inggris Page 7; 
“ kegiatan mengungkakan pikiran, pendapat, ide atau gagasan dalam bentuk tulisan dilakukan oleh manusia sejak ditemukannya huruf sebagai lambang bunyi"

"An activity expresses mind, opinion, idea or statement in written form that has been done since finding the letter as a symbol of sound by human.

Leo (2007) writing as a process of expressing ideas or things in words should be done at our leasure. Writing can be very enjoyable as long as we have the ideas and the means to achieve it.

Rahman (2010) writing is one way to express an idea, opinion, and feeling in writing form is too communication to transmit messages in which are produced in written. Zamel (1982) writing was a product of a person's search for meaning. From statement above, it can be conclude that writing was written form of what we think about everything.

\section{The Components of Writing}

Jacob in Wasmayanti (2008) points out five kinds of components in writing. They are content, organization, language use, vocabulary, and mechanics.

\section{a. Content}

The content of writing should be clear for the readers so that the readers can understand the message convey and gain information from it. In order to have a good content of writing, its content should be well unified and completed. The term is usually known as unity and completeness, which become characteristic of good writing.

\section{1) Unity}

The writing regards to have good unity, if it has some main ideas and the sentences contained in it develop that idea. The main idea is stated in the topic sentences and each or every supported sentences and related to that idea of the topic sentences. If a writer wants the writing is unified, he or she should not include the sentences that do not support the main idea of the topic sentences.

\section{2) Completeness}

Writing is said to have completeness if the main idea have been explained and developed fully completeness. The controlling idea with develop thoroughly by these of particular information. It is relative to know how complex or general 
the topic sentences by having a complete writing. It is expected that the content of writing will be clear and understandable for readers.

\section{b. Organization}

In organization of the writing concern with the ways through writer arranges and organizes the ideas in order the message in the words. There are many ways used by the writers to organize or arrange the writing the organization was mainly recognized as order. There are two parts of organization in the case, they are below:

\section{1) Coherence}

Coherence means that sticking together and in coherence essay, all the idea sticks together. A coherence text is in each idea in supporting sentence related to the topic sentence or the idea. One in which the ideas are put in the right order and never confused. The makes the writers through essay to follow sentence text.

2) Spatial order

If the purpose of the text is to tell them something looks most effective organization pattern is usually spatial, if the writers write a description of neighborhood, a room, or a holding that they want to the readers have a mental picture of what they are describing a house of building, they will probably describe the exterior and the interior of the building by moving systematically rather than haphazardly over the scene, convey the viewer of the overall plan arrangement of the scene.

\section{c. Language Use}

Coke in Wasmayanti (2002) states that language us in writing description and other forms of writing involve correct usage and point of grammar. However, considering that there are many points of grammar, the writer would like to quote a little literature about verbs, use modifier or adjective, adverbs, and participles in the writing, a modifier may other be a phrase. A single, well-chosen- modifier is of ten more effective than several used together. If it is difficult to describe with over used or warn-out modifier, find more interesting synonyms, in the dictionary. 


\section{d. Vocabulary}

Vocabulary is one of language aspect dealing the process of writing. The writers always think about putting words into the sentences and putting the sentences into the text until they can create a peace of writing. It is clear now that we cannot write or express if we do not have vocabulary. Therefore, we cannot understand the writing passage without having a lot of vocabulary.

Vocabulary as one of the important components of writing should take in to consideration by the English leaner and English teacher, because there is doubt that learning the words of the language.

\section{a. Mechanics}

The use of mechanics is due to capitalization, punctuation, and spelling appropriately. These aspects are very important, it leads the readers to understand, to recognize immediately. The use of favorable mechanic in writing will make readers easy to group the conveying ideas or the message to the written materials.

\section{Process of Writing}

The section includes a description of the activities leading to the writing of the previous essay. These activities include prewriting, writing and rewriting.

\section{a. Prewriting}

Graham and Perin (2007) explain that pre-writing engages students in activities designed to help them generate or organize ideas for their composition. Engaging the students in such activities before they write a first draft improves their quality of their writing. Prewriting activities include gathering possible information for a paper through reading or developing a visual representation of their ideas before sitting down to write.

Alexander (1990) in the section, the students are required to cluster or what they know for each topic before deciding on one topic as the subject of their report of information essay. Some students choose subtopics for two or three choices and then select the topic that yield the greatest number of subtopics. Oshima (1997) states that brainstorming is prewriting activity in which you come up with a lot of ideas about a topic on your own in small groups with your 
classmates. You quickly write down a lot of ideas that come to your mind as you are thinking about a general subject or specific topic. Follow these brainstorming steps:

1. Write down your general subject or specific topic.

2. Make a list everything that comes to your mind about it.

3. Use words, phrase, and/or sentences. Don't worry about the order of ideas, mechanics, grammar, or spelling.

4. Just keep writing down whatever comes to your mind until you run out of ideas. Because you are only brainstorming, don't be concerned if you repeat several ideas.

\section{b. Writing}

Graham and Perin (2007) the process of writing approach stress activities that emphasize extended opportunities for writing. Writing for ralaudiencs, selfreflection, personalized, instruction and goals, and cycles of planning, ad reviewing.

Litell (1981) at this point in the process of writing, you are ready to write. Simply put your pencil to paper and write. Don't fuss with the writing. Don't worry about organizing ideas. Don't fuss about spelling or punctuation. Just Write. According to Oshima (1997) there are several steps in writing process, as follows:

1. Prewritten to get previous ideas

2. Organize the ideas

3. Write the rough draft

4. Editing the rough draft

5. Write the second draft

6. Write the final draft

\section{c. Rewriting}

At this stage of the process you will need to work more carefully. Read what you have written and repair it as you can. Finally, when you are satisfied that your writing was clear and correct, write it out its final form. Write carefully. Make your work as neat as possible. 


\section{Cue Card Method}

Cue Card are small photos or picture stuck onto cards (marcos penate, 2000).Here, the use of picture was suggested by Jeremy Harmer. In hwas book entitled the Practice of English Language Teaching, he says that: "Pictures can be in the form of flashcards (smallwash card which we can hold up for our students to see), large wall pictures (big enough for everyone to see detail), cue cards (small cards which students use in pair or group work), photograph, or illustrations, typically in a textbook. (Harmer, 2001)" Cue cards are cards with words written on them that help actors and speakers remember what they have to say (Syaifoel Hardy,2011). Cue Cards are cards with photos or pictures stuck on it (Bazo, 2007).

We are so familiar with pictures. We can find many pictures in every corner of the street and in our daily lives, but in the classroom, we hardly ever found various pictures. Harmer states that there are myriad types of picture as a media in teaching; they are motion picture and still picture. A motion picture includes film, cartoon movie, etc, whereas still picture includes flash cards, wall picture, and cue cards. Again, according to Harmer cue card was cards with words or picture on that, which are used to encourage the students to respond in pair or group work.

There are several advantages of using pictures in teaching English according to Harmer (2001:134)

(1) Pictures really help to reduce preparation time. Sets of pictures can be re-used, especially it can be laminated, and can be used at any level in classes for kids, teenagers, exam classes and adults following general or business courses.

(2) When it comes to using picture stories in class, the key point was not to limit teacher to typical class activities and writing exercwases. Students need as much spoken English practice as they can get.The conclusion definition above was cue cards are combining small cards with words and picture on them to help the students to improve their ideas.

Its early use come into exwastence in the late 1930's by john Barrymore. He began to lose hwas abilty to remember the lines, so he inswasted on reading hwas dialog from the cue cards. Cue cards are made from small index cards. They 
are numbered to keep them in order. One cue card was used for one main idea. Cue cards are currently used in game shows, reality shows, comedy shows and late night talk show.

\section{The positive and negative points of cue cards:}

- Cue card are smaller than a full size script.

- It acts as safety net for a nervous or first time the students.

- The students will be more spontaneous.

- If the script was in their hands, they are not free for any gesture and there was a chance of covering their face with it.

- There are chances of muddling if they are not in an order.

These cards will be used for two purposes:

1. To write the bibliographic citation for each source to be used later in your work, you can number your citation so that you can write the number on each new card you use to take notes.

2. Each single fact, quote or summary must be written on a separate card. Even if the fact was very short (Mr. Smith,1943) you use only one card.

\section{RESEARCH METHODOLOGY}

This research used a Classroom Action Research (CAR) that consisted of planning, action, observation and reflecting. It was conducted in two cycles, each cycle compresses four meetings. Cycle one observed the students' competence in writing through cue card method. After finding the result of the cycle one, the researcher continued to the second cycle to improve the previous cycle.

This research located at eight graders of SMP Baji Minasa Makassar. The researcher chose thaws location because the researcher thought it was necessary to improve the way in teaching especially to increase the students' writing competence. This research was conducted from January to February 2013 academic year.

This classroom action research was conducted through two cycles to observe writing competence through cue card method. The research subject was the first year students with students' number 36 students that consisted of 26 women and 10 men. 
The researcher used two instruments for collecting data, namely observation sheet and test. Observation was aimed to collect data about the students' participation in teaching learning process through Cue Card method. The test was used to get about the students' writing skill through Cue Card method. It was done to know the improvement of students' writing skill. The test was given at the end of the cycle one. Then, at the end of cycle two a test was given again as the last evaluation test. Base on the last test, the researcher knew the improvement of the students' writing skill through Cue Card method.

\section{FINDINGS AND DISCUSSION}

\section{A. Findings}

The finding of the research deals with the answer of the problem statement which it aimed was to find out the improvement of the students' skill in writing descriptive text. The result of data analysis found that teaching writing skill through the use of cue card method improved the students' writing skill in terms of content and vocabulary at the eighth grade Students of SMP Bajiminasa Makassar.

\section{The Improvement of Students' writing viewed from its content}

The use of cue card method in the form of teaching method of English Writing skill improved the students' content. It was proved by the writing test as indicated by the significant difference between the score of the diagnostic test and the result of cycle I in the following table. 
Table 1. The Students' Improvement in Content

\begin{tabular}{|c|l|c|c|c|c|c|c|c|c|}
\hline \multirow{2}{*}{ No Indicators } & \multicolumn{2}{|c|}{ D - T } & \multicolumn{2}{c|}{ C I } & \multicolumn{2}{c|}{ CII } & \multicolumn{2}{c|}{$\begin{array}{c}\text { Improvement } \\
\%\end{array}$} \\
\cline { 3 - 11 } & & Score & $\%$ & Score & $\%$ & Score & $\%$ & $\begin{array}{c}\text { DT- } \\
\text { CI }\end{array}$ & CI-CII \\
\hline 1 & Unity & 5.22 & 52.20 & 6.35 & 63.50 & 7.76 & 77.60 & 28.97 & 22.20 \\
\hline 2 & \begin{tabular}{l} 
Completene \\
\cline { 3 - 11 }
\end{tabular} & 5.78 & 57.80 & 6.06 & 60.60 & 8.39 & 83.90 & 4.84 & 38.44 \\
\hline & $\sum \mathrm{X}$ & 11 & 110 & 12.41 & 124.1 & 16.15 & 160.99 & 33.81 & 60.64 \\
\hline
\end{tabular}

The data in the table above shows the students' writing skill in content as the result of calculating of the diagnostic test and students' test at the students' writing skill through cue card method, where the students' score in diagnostic test was different from the students' test in cycle I. The mean score in diagnostic test was 5.5(55.00\%) in cycle I was 6.20(62.00\%), and in cycle II was $8.07(80.70 \%)$. The assessment of cycle II was greater than cycle I and diagnostic test $(77.60 \%>63.50>52.20 \%)$ and classified as very good.

Based on the percentages above there are significant improvements of the students through cue card method. To see clearly the improvement of the students' writing viewed from its content, the following graphic was presented. 


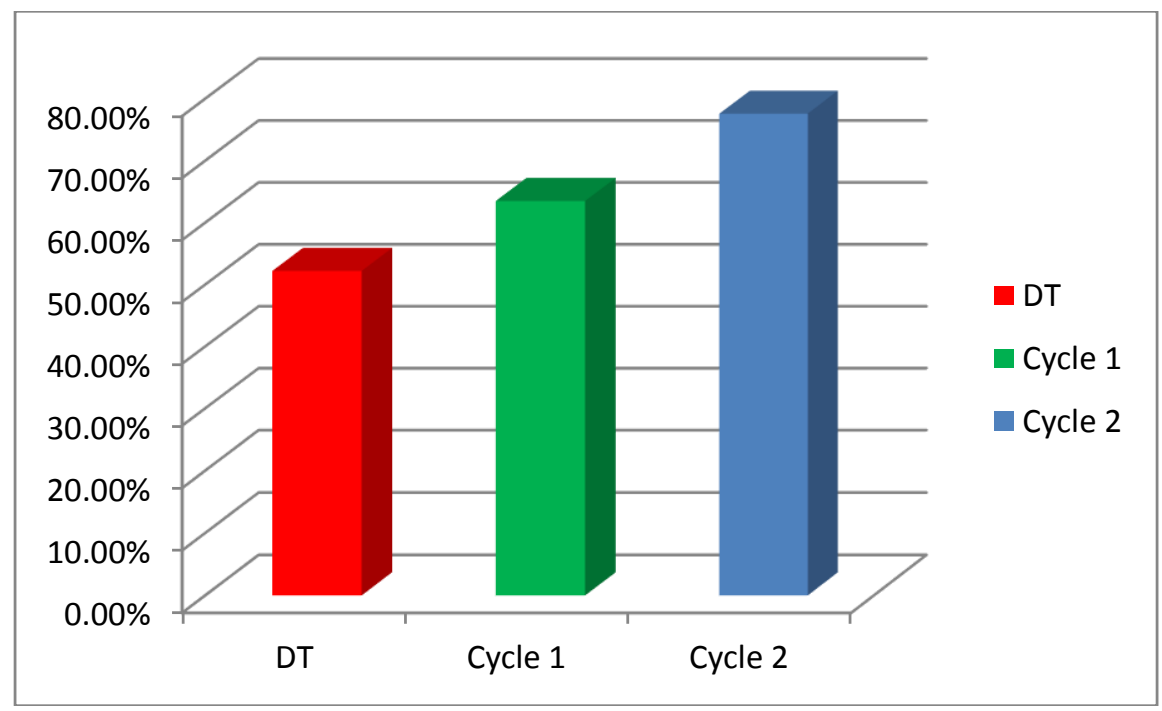

Graphic 1. The Students' Improvement in Content

The graphic above shows the significant difference of the students' improvement in the diagnostic test to the cycle I, and from cycle I to cycle II. The students' mean score in diagnostic test was $5.22(52.20 \%)$ while the students' mean score in the result of cycle 1 was $6.35(63.50 \%)$ and 7.76 $(77.60 \%)$ in cycle II. So, it means that there was improvement from the diagnostic test to the cycle 1 and from cycle I to cycle II by applying cue card method.

\section{The Improvement of the Students' writing viewed from its}

\section{Vocabulary}

The application of cue card method as one of teaching method of English writing assessed the students' progress of writing skill to the good vocabulary use with the writing test as indicated by the significant difference between the mean score of the diagnostic test and the result of the cycle I to cycle II as shown in the following table.

Table 2. The Students' Improvement in vocabulary

\begin{tabular}{|c|c|c|c|c|c|c|c|c|c|}
\hline \multirow{2}{*}{ No } & \multirow{2}{*}{$\begin{array}{c}\text { Indicato } \\
\text { rs }\end{array}$} & \multicolumn{2}{|c|}{$\mathbf{D}-\mathbf{T}$} & \multicolumn{2}{|c|}{ C I } & \multicolumn{2}{|c|}{ C II } & \multicolumn{2}{|c|}{$\begin{array}{c}\text { Improvement } \\
\%\end{array}$} \\
\hline & & Score & $\%$ & Score & $\%$ & Score & $\%$ & DT-CI & CI-CII \\
\hline 1 & Words & 5 & 50 & 6.23 & 62.30 & 7.69 & 76.90 & 24.60 & 23.43 \\
\hline 2 & Meaning & 6.56 & 65.60 & 5.90 & 59.00 & 9.09 & 90.90 & 10.06 & 54.06 \\
\hline & $\sum X$ & 11.56 & 115.6 & 12.13 & 121.3 & 16.78 & 167.8 & 34.66 & 77.49 \\
\hline & - & 5.78 & 57.80 & 6.07 & 60.70 & 8.39 & 83.90 & 17.33 & 38.745 \\
\hline
\end{tabular}

The table above shows the students' writing skill in vocabulary as the result of calculating of the diagnostic test and students' test at the students' 
writing skill through cue card method, where the students' score in diagnostic test was different from the students' test in cycle I and cycle II. The mean score in diagnostic test was 5.78, the students' test in cycle I was 6.07 and cycle II was 8.39 . The achievement of cycle II was greater than cycle I and diagnostic test $(83.90 \%>60.70 \%>57.80 \%)$ and classified as very good.

Based on the percentages above there were significant improvements of the students through cue card method. To see clearly the improvement of the students' writing viewed from its vocabulary, the following chart was presented.

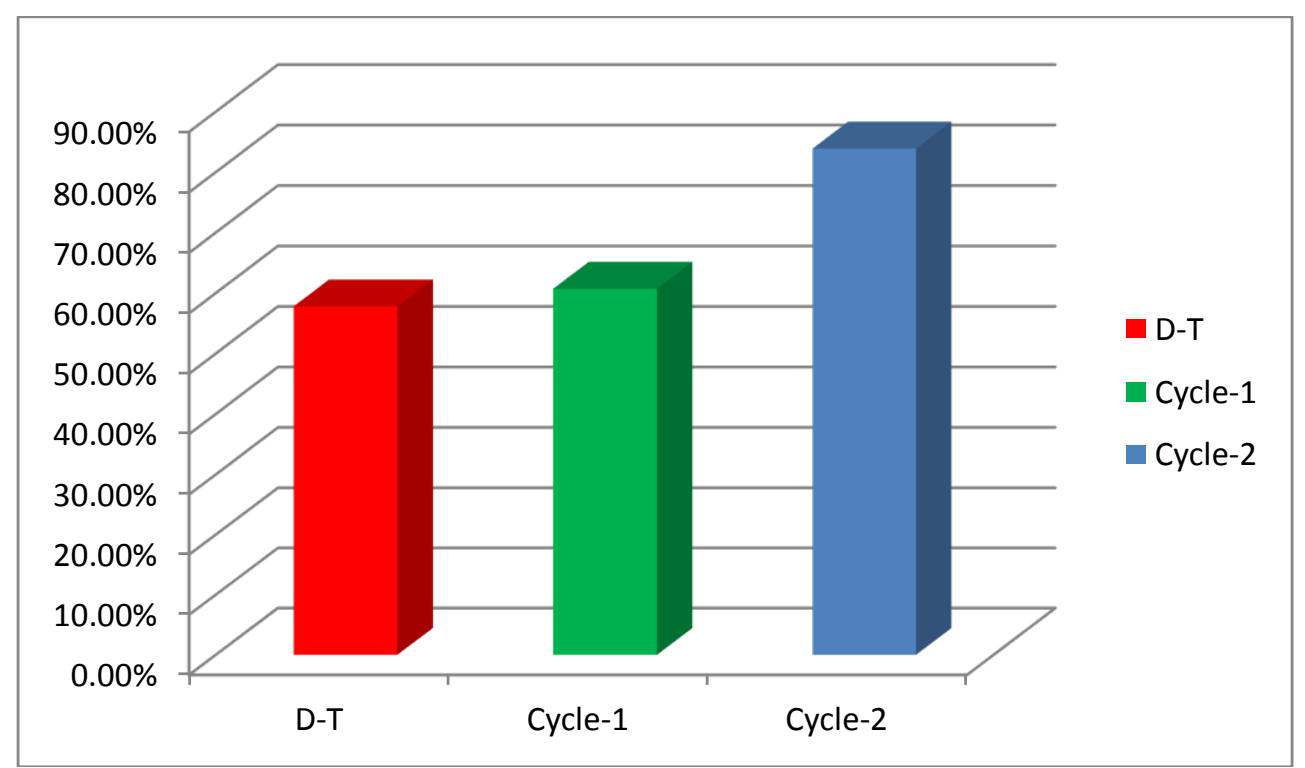

Graphic 2. The Students' Improvement in Vocabulary

The graphic above shows the significant difference of the students' mean score in the diagnostic test and result of cycle I to cycle II. The students' mean score in diagnostic test was $5.78(57.80 \%)$, while the students' mean score in the result of cycle 1 was 6.07 (60.70\%) and cycle II was $8.39(83.90 \%)$. So, it means that there was improvement form the diagnostic test to the cycle 1 and from cycle I to cycle II by cue card.

The result of the reflection in the cycle II shows that there was a significant improvement from the cycle I to the cycle II So, the researcher concludes that the indicator in writing was achieved; it means that the researcher did not need to do next cycle. It was seen by the following table: 
Table 3. The students' improvement in writing

\begin{tabular}{|c|c|c|c|c|c|c|c|c|c|}
\hline \multirow[b]{2}{*}{ No } & \multirow[b]{2}{*}{ Variables } & \multicolumn{2}{|c|}{$\mathbf{D}-\mathbf{T}$} & \multicolumn{2}{|c|}{ Cycle I } & \multicolumn{2}{|c|}{ Cycle II } & \multicolumn{2}{|c|}{ Improvement \% } \\
\hline & & Score & $\%$ & Score & $\%$ & Score & $\%$ & DT-CI & CI-CII \\
\hline 1. & Content & 5.5 & 55.00 & 6.20 & 62.00 & 8.07 & 8070 & 21.64 & 22.20 \\
\hline 2. & Organization & 5.78 & 57.80 & 607 & 60.70 & 8.39 & 83.90 & 4.84 & 37.60 \\
\hline & $\sum \mathrm{X}$ & 11.28 & 112.8 & 12.27 & 122.7 & 16.46 & 164.6 & 26.48 & 59.40 \\
\hline & - & 5.64 & 56.40 & 6.135 & 61.35 & 8.23 & 82.30 & 13.24 & 29.70 \\
\hline
\end{tabular}

The table above indicates that there was improvement of the students' writing skills from D-Test to cycle I and cycle II, which in D-Test the students' mean score (56.40\%) and categorized as average achievement. After evaluation in cycle I the students' writing skill becomes $(61.35 \%)$ and categorized as average and cycle II (82.30\%) which categorized as very good. The improvement of students' writing skill achievement from D-Test to cycle I (13.24\%). There was also significant improvement of the students' writing skill from cycle I to cycle II (29.70\%) and in D-test to cycle II (46.35\%).

The table above proved that the use of cue card in teaching and learning process was able to improve the students' writing skill after taking action in cycle I and II where the students' achievement in cycle II was greater (cycle II >cycle I>Diagnostic-Test).

To see clearly the increase of the students' writing skills, following chart was presented:

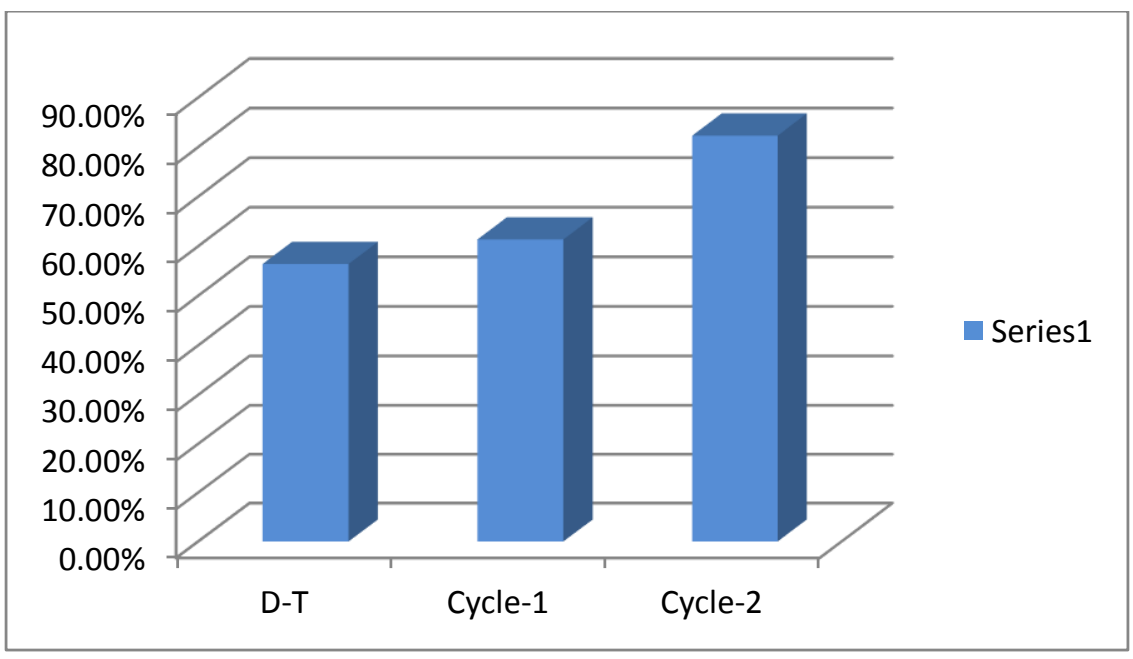




\section{Graphic 3. The Improvement of the Students' Writing Ability}

The chart above shows that the improvement of the students' writing skill in cycle II higher (82.30\%) than cycle I (61.35\%) and D-Test (56.40\%). The result of Diagnostic-Test was the lowest achievement. The students' achievement in diagnostic-test was categorized as average. After evaluation in cycle I and cycle II, there was significant improvement of the students' writing ability where the result of cycle I was categorized as good and in cycle II categorized as very good (average- good- very good).

\section{The Implementation Of Cue Card Method}

The result of the students' observation activeness in the teaching and learning process toward the application of cue card method to developing the students' writing skill at the eighth grade students of SMP Bajiminasa Makassar, which conducted in two cycles during eight meetings, was taken by observer through the observation sheet.

The researcher observed every meeting in two cycles where every cycle II the students' responses were classification into good. The students did not feel bored, but more enthusiastic to follow the teaching learning process. The students looked braver and more confident to write and express their ideas. They also admitted that they becomed active and full concentration in the classroom.

Teacher supportted and made the students more active and it caused the improvement of their writing skill by using cue card. The improvement of the students was seen in the implementation of cue card, they were : Motivating the students to improve their interest in learning process. Teacher gave the students some pictures which had correlation with the subject. Teacher explained about how to make descriptive text as material through cue card. The students was encouraged to write about anything they imagined and as they could see from the pictures. Students describe the pictures into sentences and paragraphs individually. Those pictures helped them build their ideas in constructing their writing. The pictures were things, fruit, celebrities, clothes and places. Students were motivated to write in descriptive paragraph 
by describing the pictures that the teacher provided for them. Those pictures were really helpful because sometimes students were stuck what they wanted to write. By using cue cards, students easily found the vocabulary by seeing the pictures became the ideas and students could pour them into organized paragraph. The use of cue card in teaching writing overcomed the students' difficulty in expressing their ideas.

The average of the students' activeness in teaching and learning process through observation sheet by observer. The percentages of the cycle I from the first meeting to the fourth meeting are fifty six point ninety four percent, sixty five point twenty eight percent, sixty five point eighty seven percent, and sixty eight point seventy five percent. Moreover, the percent of the cycle II from the first meeting to the fourth meeting are sixty three point nineteen percent, seventy one point fifty two percent, seventy five percent and eighty two point sixty three percent. In addition, the average scores in every cycle. In cycle I was sixty four point twenty one percent and in cycle II was seventy three point eighty five percent.

\section{Observation Result}

The following table and graphic showed the observation result of the students' activeness in learning writing from cycle I to cycle II.

Table 4. The students' observation result during teaching and learning process

\begin{tabular}{|c|c|c|c|c|}
\hline \multirow{2}{*}{ Cycles } & \multicolumn{4}{|c|}{ Activeness } \\
\cline { 2 - 5 } & $\begin{array}{c}\mathbf{1}^{\text {st }} \text { Meeting } \\
(\boldsymbol{\%})\end{array}$ & $\begin{array}{c}\mathbf{2}^{\text {nd }} \text { Meeting } \\
(\boldsymbol{\%})\end{array}$ & $\begin{array}{c}\mathbf{3}^{\text {rd }} \text { Meeting } \\
(\boldsymbol{\%})\end{array}$ & $\begin{array}{c}\mathbf{4}^{\text {th }} \text { Meeting } \\
(\boldsymbol{\%})\end{array}$ \\
\hline Cycle 1 & 51.38 & 58.33 & 63.19 & 71.52 \\
\hline Cycle 2 & 59.02 & 71.52 & 74.30 & 85.41 \\
\hline
\end{tabular}

The students' observation was shown through the graphic below: 


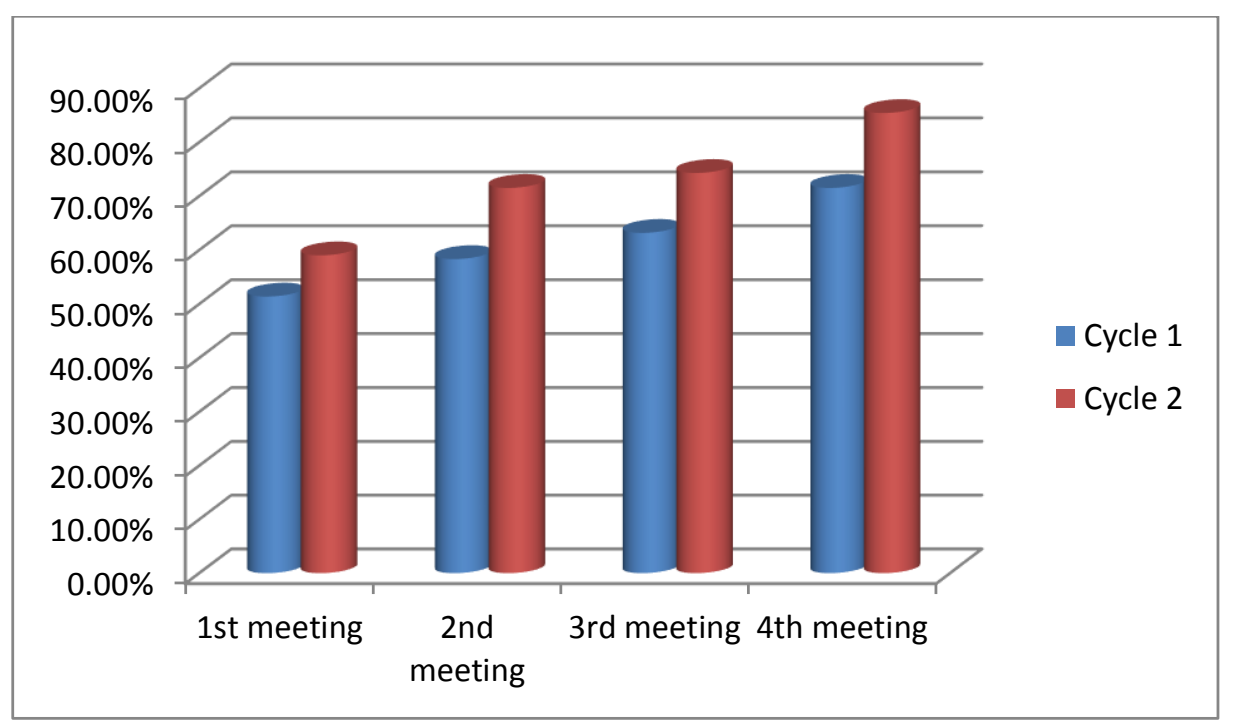

Graphic 4: The Improvement of the Students'Activeness during Teaching and Learning Process

Table 4 and graphic 4 above show that in cycle I the students' activeness in the $1^{\text {st }}$ meeting was $51.38 \%$, the $2^{\text {nd }}$ meeting was $58.33 \%$, the $3^{\text {rd }}$ meeting was $63.19 \%$ and the $4^{\text {th meeting }}$ was $71.52 \%$. In cycle II students' activeness in the $1^{\text {st }}$ meeting was $59.02 \%$, the $2^{\text {nd }}$ meeting was $71.52 \%$, the $3^{\text {rd }}$ meeting was $74.30 \%$ and the $4^{\text {th }}$ meeting was $85.41 \%$. Based on the interpretation of the table and the graphic above indicate that the activeness of students in learning process always grow up from the first meeting in cycle I. For the first meeting of cycle II students probably get bored of material so their activeness decrease but researcher tries to engage them. It made their activeness increase again until the last meeting in cycle II.

\section{DISCUSSION}

In this part, the discussion covering the interpretation of finding derived from the result of findings was based on the problem statements was:

"How does cue card method improve the students' writing skill at the Eighth Grade Students of SMP Bajiminasa Makassar ?”

To know clearly the discussion of finding in writing project, following was presented:

\section{a. Content}


The improvement of the students' skills to write good writing through Cue Card method has an effective effect. Where, the teacher finds in the diagnostic test of content that the students just get score about 5.5, it means that it was far from the target, but after implies Cue Card; the students get mean score about 6.20 in the cycle I and 8.07 in cycle II. It means that the target has been achieved.

Following was presented the improvement of students' writing viewed from its content percentage as the result of teaching learning observation:

The percentage of the students' content in writing diagnostic-test indicates that 5 students (13.9\%) get good, 29 students (80.6\%) get average, 2 students $(5.56 \%)$ poor and none of students for the very good and excellent classification.

After taking an action in cycle I through cue card method, the percentage of the students' content was 6 students (16.7\%) get very good, 22 students $(61.1 \%)$ get good, and 8 students $(22.2 \%)$ get average and none of the students for other classification.

In cycle II, the percentage of the students' content was 2 student $(5.56 \%)$ get excellent, 34 students $(94.4 \%)$ get very good, and none of the students for other classification. The result above also proveed that the use of cue card was able to improve the students' content where the result of cycle II was higher than cycle $\mathrm{I}$ and diagnostic-test (Cycle II $>$ Cycle I $>$ Diagnostic-Test).

\section{b. Vocabulary}

After implementation of cue card method in the class, the teacher found that the mean score of diagnostic test in vocabulary 5.78 . In the cycle I, the students just got 6.07, and in the cycle II, the students got 8.39. It means that the target score was achieved in the cycle II.

Following was presented the improvement of students' writing viewed from its vocabulary percentage as the result of teaching learning observation.

The percentage of the students' vocabulary in diagnostic-test indicates that 4 students (11.11\%) get good, 25 students (69.4\%) get average, 7 students $(19.4 \%)$ get poor and none of students for the very good and excellent.

After taking an action in cycle I through vocabulary, the percentage of the students' writing viewed from its Vocabulary was 5 students (13.9\%) get very 
good, 20 students (55.6\%) good, 11 students (30.6\%) get average and none of the students for excellent classification.

In cycle II, the percentage of the students' writing viewed from its vocabulary was 2 student $(5.56 \%)$ get excellent, 28 students $(55.6 \%)$ get very good, 6 students (16.7\%) get good and none of the students for other classification. The result above also proved that use of cue card was able to improve the students' vocabulary where the result of cycle II was higher than cycle I and diagnostic-test (Cycle II $>$ Cycle I $>$ Diagnostic-Test).

\section{CONCLUSION}

Based on the findings and discussion in the previous chapter, the researcher inferential in the following conclusion.

1. The implementation of Cue card method improved the students' writing skills. It was needed in English language teaching and learning in improving their skills to organize their idea. Cue card method gave them more chance and times to collect their ideas related to the topic and organized them into writing. The implementation of cue card also gave the students' freedom to organize their ideas, so they decided the content that they wanted to write their experience and they write the content under the guidance of the teacher.

2. The students' writing skills in writing viewed from its content of diagnostic test was 5.5, in cycle I was 6.20, and cycle II was 8.07. The students' progress from the diagnostic test to the cycle I was $21.64 \%$, and the cycle I to the cycle II was $22.20 \%$.

3. The students' writing skills in writing viewed from its of diagnostic test vocabulary was 5.78 , the cycle I was 6.07 , and cycle II was 8.39 . The students' progress from the diagnostic test to the cycle I was $4.84 \%$, and the cycle I to the cycle II was $37.60 \%$.

\section{BIBLIOGRAPHY}

Bereiter,Scarmadalia. 1983. Writing, Process and Teaching. Books.google.co.id/book wasbn $=041577116 \ldots$

Breveton. 1982. A plan for writing skills. New York: CBS College Publishing 
Candling N, Chrwastoper.1978. The communicative teaching of English. London. Longman Group

Dalle, Muh. Basri, 2007. Fundamentals of Study Methodology. : Universitas Muhammadiyah.

Depdiknas. 2004. GBPP. Bahasa Inggris. Jakarta: Diknas

Gay,L.R,1987. Educational Study. Competencies for Analyses and Application. Columbus: Charles E.Merill Publishing,co.

George, Wwashon and Julia M.Burks, 1980. Let's Write English. New York: American Book Company.

Gerot, L and P Wignell. 1994. Making Sense of Functional Grammar. Sydney: Gerd Stabler.

Hamalik, O. 1993. Media Pendidikan. Bandung: PT. Citra Aditya Bakti

Harmer, J. 2001. The Practice of English Language Teaching (rev. ed). London: Longman

Harrwas, D.P. 1969. Testing English as a Second Language. New York: McGraw Hill Company.

Heaton, J.B. 1975. Writing English Language Text. London: Longman Group Limited

Kohonen, V ET. al. 2001. Experiential learning in foreign language education. London: Longman

Larsen-Freeman, D. 2000. Techniques and Principles in language teaching. Oxford: Oxford University Press

McDaugal,Littell \& company. 1981. Basic Skills in English. New York. United States of America. 